JURNALYOGA DAN KESEHATAN

JURUSAN YOGA KESEHATAN

FAKULTAS BRAHMA WIDYA

IHDN DENPASAR
Vol. 3 No. 2 September 2020

ISSN : 2621-0185 (Cetak)

ISSN : 2722-9440 (Online)

http://ejournal.ihdn.ac.id/index.php/jyk

\title{
Komunikasi Transendental dalam Yoga
}

\author{
Putu Ayu Sri Kumala Dewi ${ }^{1}$, I Made Gde Puasa ${ }^{2}$ \\ SD Saraswati 3 Denpasar, Institut Hindu Dharma Negeri Denpasar \\ email: srikumaladewi1@gmail.com ${ }^{1}$, madepuasa@gmail.com ${ }^{2}$
}

Diterima tanggal 17 Juli 2020, diseleksi tanggal 15 Agustus 2020, dan disetujui tanggal 27 Agustus 2020

\begin{abstract}
Transcendental communication means communication between humans and their God and entering into the field of religion, participants in transcendental communication are humans with their Lord. But the discussion is little in the discipline of communication, even though this is more important than other forms of communication, especially in people who believe in the existence of God. This transcendental communication in Hinduism can be seen in a yoga activity. Yoga is an activity that aims to get closer to God. Yoga is done by uniting the mind, body, and soul with the aim of uniting oneself with God itself can be a unique study in transcendental communication. This article aims to discuss why yoga can be said to be a process of transcendental communication and the process of transcendental communication that occurs in yoga. This article uses the theory of symbolic interactionism as a scalpel in studying both problem statements. As for the results of the discussion of this article that by realizing the meaning of awareness of the meaning and motives of individuals, yoga practitioners carry out a discipline of awareness about cognitive focus and calm to minimize mental imbalances so that ultimately able to create an individual transformation and communication of mental transfiguration between individuals with God that is in the individual itself. The process of transcendental communication takes place in yoga activities because a yogi is aware of the existence of God and with the aim to get closer and unite his mind, body and soul with God himself.
\end{abstract}

Keywords: Communication; Transcendental; Yoga.

\section{ABSTRAK}

Komunikasi transendental berarti komunikasi antara manusia dengan Tuhnannya dan masuk ke dalam bidang agama, partisipan dalam komunikasi transendental adalah manusia dengan Tuhannya. Namun pembahasannya sedikit dalam disiplin ilmu komunikasi, padahal ini lebih penting dari bentuk komunikasi lainnya khususnya pada orang yang mempercayai adanya Tuhan. Komunikasi transendental ini dalam Hindu dapat dilihat pada sebuah aktivitas yoga. Yoga adalah sebuah aktivitas yang bertujuan untuk mendekatkan diri dengan Tuhan. Yoga dilakukan dengan menyatukan antara pikiran, tubuh, serta jiwa dengan tujuan menyatukan diri dengan Tuhan itu sendiri dapat menjadi kajian unik dalam komunikasi transendental. Artikel ini bertujuan untuk membahas alasan yoga dapat dikatakan sebagai sebuah proses komunikasi transendental dan proses komunikasi transendental yang terjadi dalam yoga. Artikel ini menggunakan teori interaksionisme simbolik sebagai pisau bedah dalam mengkaji kedua rumusan masalah. Adapun hasil pembahasan dari artikel ini bahwasanya dengan menyadari arti dari kesadaran terhadap makna dan motif individu, pelaku yoga melaksanakan sebuah disiplin kesadaran tentang fokus dan ketenangan kognitif untuk memperkecil ketidakseimbangan jiwa sehingga pada akhirnya mampu menciptakan sebuah transformasi individu dan komunikasi transfigurasi mental yang hakiki antara diri individu dengan Tuhan yang terdapat dalam diri individu itu sendiri. Proses komunikasi transendental terjadi dalam aktivitas yoga karena seorang yogi menyadari keberadaan tuhan serta dengan tujuannya untuk mendekatkan diri serta menyatukan pikiran, tubuh dan jiwanya dengan Tuhan itu sendiri.

Kata Kunci: Komunikasi; Transendental; Yoga. 


\section{PENDAHULUAN}

Komunikasi transendental berarti komunikasi antara manusia dengan Tuhannya dan masuk ke dalam bidang agama, partisipan dalam komunikasi transendental adalah manusia dengan Tuhannya. Namun pembahasannya sedikit dalam disiplin ilmu komunikasi, padahal ini lebih penting dari bentuk komunikasi lainnya, walaupun bentuk komunikasi transendental tidak bisa diamati secara empiris, tetapi dapat memengaruhi nasibnya baik didunia maupun akhirat (https://www.kompasiana.com, diakses pada tanggal 09 Juni 2020). Setelah penulis menganalisa aktivitas dalam yoga, penulis menyimpulkan bahwa komunikasi transendental ini dapat dilihat pada sebuah aktivitas yoga.

Chawidhri dalam Perbowosari (2018:172), kata yoga berasal dari kata yuj yang artinya menyatukan atau menghubungkan diri dengan Tuhan. Adapun tujuan yoga adalah untuk menggabungkan diri individu dengan diri yang Universal (Sang Hyang Widhi). Dalam latihan awal, yoga membangun tubuh yang sehat dan melatih pikiran, kemudian latihan akhir bertujuan untuk menuntun seseorang pada kesadaran atman dalam diri kita.

Umat Hindu memiliki lima keyakinan yang disebut panca sradha, yang salah satunya adalah percaya terhadap atman yang merupakan percikan kecil dari Tuhan atau brahman itu sendiri. Oleh sebab itu dapat dikatakan pula di dalam diri manusia itu sendiri terdapat Tuhan itu sendiri. Hal inilah yang menurut penulis sangat menarik dikaji. Terdapat proses komunikasi transendental yang terjadi dalam aktivitas yoga yang dilakukan dengan penuh kesadaran diri dilakukan dengan memerhatikan diri sendiri yang merupakan tempat Tuhan itu sendiri.Sebuah karya ilmiah memiliki fokus bahasan yang jelas sehingga agar tidak terjadi kekaburan permasalahan serta untuk membatasi topik bahasan permasalahan dalam tulisan ini maka penulis membatasi permasalahan yang akan dikaji dalam artikel ini. Artikel ini bertujuan untuk membahas mengenai alasan yoga dapat dikatakan sebagai sebuah proses komunikasi transendental dan proses komunikasi transendental yang terjadi dalam yoga

\section{PEMBAHASAN}

\subsection{Komunikasi Transendental pada Aktivitas Yoga}

Komunikasi adalah proses penyampaian pesan dari seorang komunikator kepada komunikan melalui sebuah media yang menghasilkan efek. Dari definisi sederhana ini kemudian timbul pertanyaan bagaimana menjalin komunikasi dengan Tuhan yang secara kasat mata tidak dapat dilihat hanya bisa diyakini dan dirasakan keberadaannya. Bagaimana menghadirkan sosok komunikator atau komunikan dalam proses komunikasi ini, media seperti apa yang digunakan, 
dan bagaimana melihat efek yang dihasilkan dalam proses komunikasi tersebut. Hal inilah yang ingin diungkap dalam komunikasi transendental. Komunikasi yang melibatkan manusia dengan Tuhannya itulah yang sering disebut komunikasi transendental. Manusia merupakan makhluk sosial yang tidak dapat berdiri sendiri, ia membutuhkan orang lain untuk mempertahankan eksistensinya. Manusia harus membangun hubungan horisontal yakni dengan manusia lainnya dan vertikal dengan Tuhannya. Hubungan itu akan membawa seorang individu menjadi manusia paripurna. (Suryani, 2015:151)

Ibarat komunikasi antar manusia, komunikasi transendental dilakukan untuk menyampaikan pesan-pesan baik berupa informasi maupun kehendak seseorang kepada komunikan, dalam hal ini komunikannya bersifat supranatural (Prakasa, 2018: 156). Ketidakmampuan manusia berhubungan langsung dengan Tuhan melalui batiniah, menimbulkan cara lain untuk mencapai alam Ketuhanan. Masyarakat agama Hindu umumnya dan Bali khususnya, umat Hindu dalam berkomunikasi dengan Ida Sang Hyang Widhi atau Tuhan tidak hanya melalui hubungan spiritual namun juga melalui media-media tertentu. Hal ini erat kaitannya pada aktivitas yoga yang menjadi salah satu ajaran umat Hindu yang tertuang dalam veda.

Menurut Svāmī Satyānanda Sarasvatī, yoga berarti pengalaman dari keutuhan atau kesatuan dengan keberadaan batin. Kesatuan ini muncul setelah menghancurkan dualitas pikiran dan masalah ke dalam kesadaran tertinggi Sarasvati (2002: 1). Penjelasan mengenai yoga juga disebutkan di dalam kitab Bhagavadgita, sloka 6.2 yang memuat:

Yam sannyasam iti prahur

Yogam tam viddhi pandawa

Na hy asannyasta-sankalpo

Yogi bhavati kascana

Terjemahan:

Hendaknya engkau mengetahui bahwa apa yang disebut melepaskan sama dengan yoga atau mengadakan hubungan antara diri kita dengan Yang Mahakuasa, wahai putera Pandu, sebab seseorang tidak akan pernah dapat menjadi yogi kecuali ia melepaskan keinginan untuk memuaskan indria-indria.

Swami Prabhupāda menjelaskan makna dari sloka bhagavadgita tersebut bahwa yoga merupakan salah satu latihan untuk mengekang gerak-gerak indria dari ikatan material yang membawa pada kesengsaraan sekaligus melatih kesadaran akan Krsna (Prabhupāda, 2006:307). Menurut Ramesh (2015: 35), yoga adalah keadaan batin yang sejahtera yang kita rasakan saat terjadi keharmonisan interaksi antara tubuh, pikiran dan jiwa. Sebagai cara hidup, yoga adalah 
jalan penemuan diri. Melalui asanas dan meditasi, yoga mempromosikan kesehatan fisik, keseimbangan mental dan kedamaian spiritual. Secara spiritual yoga berarti penyatuan dan merujuk pada keadaan tercerahkan. Sebagai seni dan sains, yoga membantu kita mengembangkan cara hidup yang lebih sehat dan seimbang.

Ramesh (2015: 34) juga mengatakan ada dua kategori dalam latihan yoga, pertama yang tujuan utamanya untuk kesehatan fisik dan tujuan sekundernya untuk pertumbuhan spiritual. Ngurah Nala (1989: 77) dalam bukunya yang berjudul "Ayurveda, Ilmu Kedokteran Hidndu”, menyebutkan " yoga bukanlah sekedar hanya masalah olah fisik saja, tetapi jauh lebih luas dari itu. Menyangkut jasmani, mental dan rohani. Yoga selain bermanfaat dalam usaha pencegahan (preventif), karena mampu meningkatkan fungsi alat-alat tubuh dan daya tahan tubuh terhadap berbagai gangguan, juga merupakan salah satu cara penyembuhan (terapi) baik fisik maupun mental).

Berdasarkan penjelasan tersebut, dapat disimpulkan bahwa yoga adalah suatu usaha atau aktivitas untuk mendekatkan diri dengan Tuhan dengan berbagai bentuk seperti dalam Astangga Yoga. Yoga yang dimaksudkan dalam penelitian ini adalah aktivitas yoga yang dilakukan secara holistik sesuai dengan ajaran agama Hindu. Ajaran Yoga merupakan bagian dari 6 filsafat diantaranya yaitu Nyaya, Waisesika, Samkhya, Yoga, Mimamsa dan Wedanta. Dimana ajaran Samkhya dan Yoga sering dibicarakan secara berurutan karena memiliki kesamaan). Dalam melaksanakan Yoga, Rsi Patanjali mengajarkan Astangga Yoga yaitu delapan macam disiplin untuk memungkinkan seseorang dapat mencapai tingkat kesucian batin dan kesempurnaa citta. Delapan disiplin itu adalah: Yama, Niyama, Asana, Pranayama, Pratyahara, Dharana, Dhyana dan Samadhi.

Kata yoga memberi definisi tentang cara bagaimana Tuhan itu bisa bersatu dengan manusia. Banyak cara yang mungkin ditempuh oleh manusia untuk mencapai tujuan itu. Dapat dikatakan seperti banyak ada agama, banyak juga ada jalan. Filsafat Hindu mengenal empat cara pokok (yoga) untuk mencapai tujuan itu. Cara itu adalah Jnana yoga, Karma yoga, Bhakti yoga dan Raja yoga. Masing-masing yoga merupakan cara tersendiri untuk mendekatkan diri pada Tuhan dan ketika tujuan akhir itu tercapai, agaknya keempat yoga itu berpadu menjadi satu. Cinta kasih yang tertinggi, ilmu pengetahuan yang hebat, semadi yang sejati, tindakan yang benar, dan paling mulia pada akhirnya sama dan tidak dapat dibedakan antara satu dengan yang lainnya. Melaksanakan ajaran yoga mengajarkan bahwa betapa pentingnya memerhatikan diri karena diri adalah sthana Tuhan itu sendiri. Seperti yang tertuang pada kutipan sloka berikut ini. 
Ambhasyapare bhuwanasya madhye nakasya prsthe mahato mahiyam, sukrena jyotimsi samanupruwistah prajapatis carati garbhe antah.

(Mahanarayana Upanisad, I.1)

Terjemahan :

Sang Pencipta, yang hadir dalam air tanpa tepi, pada bumi dan di atas surga, dan yang lebih besar dari yang besar, setelah memasuki kecerdasan makhluk yang bersinar dalam wujud benih, bertindak dalam janin (yang tumbuh menjadi makhluk hidup yang dilahirkan.

Berdasarkan kutipan sloka tersebut dapat disimpulkan bahwa Tuhan sejatinya berada pada setiap diri makhluk hidup. Ketika melakukan aktivitas yoga, sesungguhnya konsentrasi yang diberikan pada diri yang ditunjukkan dengan berbagai aktivitas seperti mudra, asana, pranayama dalam yoga adalah sebuah bentuk komunikasi transendental dengan Tuhan sebagai tujuan dalam menyatukan diri dengan-Nya. Selain itu berbagai bentuk simbol-simbol berupa gerakan asanas dalam yoga dan aktivitas-aktivitas lain seperti mudra dan pranayama adalah sebuah bentuk interaksi simbolik yang tentunya memiliki makna dalam mendukung aktivitas yoga.

Menurut teori interaksi simbolik, kehidupan sosial dan transendental pada dasarnya adalah interaksi manusia yang menggunakan simbol-simbol, mereka tertarik pada cara manusia menggunakan simbol-simbol yang merepresentasikan apa yang mereka maksudkan untuk berkomunikasi dengan sesamanya maupun Tuhannya sekaligus pengaruh yang ditimbulkan dari penafsiran simbol-simbol tersebut terhadap perilaku pihak-pihak yang terlibat dalam interaksi sosial (Sobur, 2004:199). Begitu juga interaksi yang dilakukan pada saat melakukan Yoga. Manusia berkomunikasi dengan Tuhan menggunakan simbol-simbol yang ditunjukkan melalui sikap dan perilaku kehidupannya yang berkaitan dengan yoga.

Sesuai dengan sebuah teori yaitu interaksionisme simbolik yang secara ringkas teori interaksionise simbolik didasarkan pada premis premis sebagai berikut : a. Individu merespon suatu situasi simbolik, mereka merespon lingkungan termasuk obyek fisik (benda) dan obyek sosial (perilaku manusia) berdasarkan media yang dikandung komponen-komponen lingkungan tersebut bagi mereka. b. Makna adalah produk interaksi sosial, karena itu makna tidak melihat pada obyek, melainkan dinegosiasikan melalui penggunaan bahasa, negosiasi itu dimungkinkan karena manusia mampu mewarnai segala sesuatu bukan hanya obyek fisik, tindakan atau peristiwa (bahkan tanpa kehadiran obyek fisik, tindakan atau peristiwa itu) namun juga gagasan yang abstrak. c. Makna yang diinterpretasikan individu dapat berubah dari waktu ke waktu, sejalan dengan perubahan situasi yang ditemukan dalam interaksi sosial, perubahan interpretasi dimungkinkan karena individu dapat melakukan proses mental, yakni berkomunikasi dengan dirinya sendiri (Sobur, 2004:199). 


\subsection{Proses Komunikasi Transendental pada Aktivitas Yoga}

Proses komunikasi yaitu bagaimana komunikator menyampaikan pesan kepada komunikannya, sehingga dapat menciptakan suatu persamaan makna antara komunikan dengan komunikatornya. Proses komunikasi ini bertujuan untuk dapat menciptakan komunikasi yang lebih efektif (sesuai dengan tujuan komunikasi pada umumnya). Proses komunikasi dapat terjadi apabila ada interaksi antar manusia dan juga ada penyampaian pesan untuk dapat mewujudkan motif komunikasi. Melalui komunikasi ini sikap dan juga perasaan seseorang atau sekelompok orang dapat dipahami oleh pihak lain. Sebelum memasuki pembahasan proses komunikasi transendental, berikut ini adalah unsur-unsur komunikasi transendental pada aktivitas yoga terjadi sebagai berikut.

1. Komunikator

Pada komunikasi transendental, komunikatornya adalah yogi atau manusia yang melakukan yoga itu sendiri. Serta, Tuhan itu sendiri yang menyampaikan pesan melalui ajaran-ajaran veda.

2. Komunikan

Komunikan dalam komunikasi transendental adalah yogi dan Tuhan itu sendiri. Walaupun bentuk Tuhan tidak dapat dijelaskan secara empiris, namun, yogi meyakini tuhan itu sendiri yang berada di dalam tubuhnya. Sehingga, dapat dikatakan juga, komunikasi yang terjadi adalah dalam bentuk komunikasi interpersonal.

3. Pesan

Pesan adalah apa yang disampaikan oleh komunikator. Pesan seharusnya mempunyai inti pesan (tema) sebagai usaha mengubah sikap dan tingkah laku komunikan. Pesan dapat disampaikan secara panjang lebar namun harus tetap diarahkan kepada tujuan akhir dari komunikasi.

Pesan-pesan bisa disampaikan secara langsung (lisan/ face to face) atau dengan menggunakan media/saluran. Pesan pun dapat bersifat informatif, persuasif, dan coercive. Informatif berarti memberikan kerterangan-keterangan dan kemudian dapat mengambil kesimpulan sendiri. Dalam situasi tertentu pesan informatif lebih berhasil daripada pesan persuasif misalnya pada kalangan cendikiawan. Pesan yang disampaikan oleh manusia melalui yoga jelas tujuannya yaitu untuk mendekatkan bahkan menyatukan diri kepada Tuhan, sedangkan pesan yang disampaikan Tuhan terdapat dalam kitab suci veda.

4. Media

Saluran komunikasi selalu menyampaikan pesan yang dapat diterima melaui panca indera atau menggunakan media. Komunikasi yang terjadi antara manusia dengan 
Tuhannya menggunakan veda sebagai saluran penyampai pesan-pesan Tuhan kepada manusia. Sementara saat manusia berkomunikasi dengan Tuhannya maka saluran yang digunakan tidak bisa terlihat dan terdeteksi oleh mata biasa. Saluran tersebut hanya dirasakan dan diketahui oleh manusia sebagai penerima, sebaliknya manusia terkadang jadi penyampai atau sumber. Hal ini nampak jelas dalam proses seorang manusia saat melakukan yoga yang ditunjukkan dalam berbagai bentuk aktivitas yoga.

5. Effect

Effect adalah hasil akhir dari suatu komunikasi, yakni sikap dan tingkah laku orang, sesuai atau tidak sesuai dengan yang diinginkan oleh komunikator. Jika sikap dan tingkah laku orang lain itu sesuai, maka berarti komunikasi itu berhasil, demikian pula sebaliknya. (Suryanto, 2015: 194)

Proses komunikasi transendental pada aktivitas yoga meliputi dua proses yakni proses verbal dan proses non verbal. Komunikasi verbal adalah penyampaian makna dengan menggunakan bahasa dan kata-kata baik secara lisan maupun secara tertulis (Hardjana, 2003 : 22). Proses verbal dalam aktivitas yoga tejadi ketika puja atau mantra yang digunakan yang digunakan pada saat aktivitas yoga. Sedangkan proses nonverbal komunikasi transendental mapajejiwan meliputi gerak asana, mudra seperti suryanamaskara yaitu pemujaan kepada matahari, berbagai bentuk sikap tubuh yang menyerupai bentuk hewan, tumbuhan serta berbagai simbol-simbol ciptaan Tuhan lainnya. Mulyana (2010 : 347) menjelaskan bahwa komunikasi non verbal merupakan komunikasi yang menggunakan pesan-pesan non verbal untuk melukiskan peristiwa atau komunikasi diluar kata-kata terucap maupun tertulis. Proses non verbal dalam aktivitas yoga berupa asanas atau sikap tubuh serta mudra atau gerak sikap tangan yang bertujuan untuk menyatukan seluruh kesadaran terhadap Tuhan.

\section{PENUTUP}

Berdasarkan hasil pembahasan tersebut dapat disimpulkan bahwa dengan menyadari arti dari kesadaran terhadap makna dan motif individu, pelaku yoga melaksanakan sebuah disiplin kesadaran tentang fokus dan ketenangan kognitif untuk memperkecil ketidakseimbangan jiwa sehingga pada akhirnya mampu menciptakan sebuah transformasi individu dan komunikasi transfigurasi mental yang hakiki. Proses komunikasi transendental terjadi dalam aktivitas yoga karena seorang yogi menyadari keberadaan tuhan serta dengan tujuannya untuk mendekatkan diri serta menyatukan pikiran, tubuh dan jiwanya dengan Tuhan itu sendiri. 


\section{DAFTAR PUSTAKA}

Hardjana, Agus M. 2003. Komunikasi Intrapersonal \& Interpersonal. Yogyakarta : Penerbit Kanisius.

Johnson. 1986. Teori Sosiologi Klasik dan Modern. Jilid 1. PT Gramedia: Jakarta.

Mulyana, Dedi. 2010. Ilmu Komunikasi Suatu Pengantar. Bandung : Rosdakarya.

Nala, Ngurah. 2002. Ayurveda Ilmu Kedokteran Hindu. Denpasar: Upada Sastra.

Perbowosari, Heny. 2018. Optimalisasi Kecerdasan Spiritual Anak Melalui Yoga Asanas. Jurnal Ilmu Agama. 1(2), 166-177. Retrieved from http://jayapanguspress.penerbit.org/index.php/kamaya/article/view/77, diakses pada tanggal 18 Juni 2020 pukul 20.09 Wita.

Prabhupāda, Sri Srimad A.C. Bhaktivedanta Swami. 2006. Bhagavad Gītā Menurut Aslinya. Jakarta: Hanuman Sakti.

Prakasa, Sangra Juliano. 2018. Komunikasi Transendental dalam Upacara Keagamaan "OgohOgoh” Bagi Masyarakat Hindu di Desa Yehembang Provinsi Bali. Jurnal Ilmu Politik dan Komunikasi Fisip Unikom. 8(1), 153-166. Retrieved from https://repository.unikom.ac.id/id/eprint/56817, diakses pada tanggal 18 Juni 2020 pukul 19.08 Wita.

Pudja, G. 2005. Bhagawad Gita (Pancama Veda), Surabaya: Paramita.

Puspa, I A. Tary, Dkk. 2019. Komunikasi Simbolik dalam Penggunaan Upakara Yajna pada Ritual Hindu. Jurnal Ilmiah Widya Duta. 14(1), 20-28. Retrieved from http://ejournal.ihdn.ac.id/index.php/VidyaDuta/article/view/1040/887, diakses pada tanggal 18 Mei 2020 pukul 14.40 Wita.

Sarasvati, Swami Satyananda, 2002. Asana, Pranayama, Mudra, dan Banda, Surabaya: Penerbit Paramita.

Sobur, Alex. 2004. Semiotika Komunikasi. Bandung: Rosda Karya.

Suryani, Waidah. 2015. Komunikasi Transendental Manusia - Tuhan. Jurnal IAIN Gorontalo. 12(1), 150-163. Retrieved from http://journal.iaingorontalo.ac.id/index.php/fa, diakses pada tanggal 03 Mei 2020 pukul 08.40 Wita.

Suryanto. (2015). Pengantar Ilmu Komunikasi (1). Bandung: CV Pustaka.

Sumber Virtual:

https://www.kompasiana.com/syfaqulbi/59190b5e4423bd6508e8729b/komunikasi-transendental, diakses pada tanggal 09 Juni 2020 pukul 17.05 Wita. 